\title{
Etiological treatment of protozoer diarrhea in neonatal ruminants
}

\author{
İlker Yusuf AKINCI, Metin Koray ALBAY
}

Burdur Mehmet Akif Ersoy University, Faculty of Veterinary Medicine, Department of Internal Medicine, Burdur/TURKEY

Key Words:
diarrhea
ruminant
cryptosporidiosis
coccidiosis
giardiasis

Received: 28.01 .2020

Accepted: 20.03 .2020

Published Online: 30.04 .2020

Article Code:681052

Correspondence:

MK. ALBAY

(mkalbay@mehmetakif.edu.tr)

ORCID:

IY. AKINCI: 0000-0002-8507-7458

MK. ALBAY: 0000-0003-4141-4181

\section{INTRODUCTION}

Diarrhea that is caused by infectious or non-infectious factors and is characterized by the removal of large amounts of faeces frequently and watery consistency is a crucial symptom in animals (1). As it is common all over the world, it is one of the main problems for not only cattle and sheep but also goat breeding in our country (2). Diarrhea is mostly observerd in calves, lambs and kids through the neonatal period. There are many infectious (bacterial, viral, parasitic, protozoan, fungal) and non-infectious (alimenteric, toxic, allergic, etc.) reasons in the etiology of diarrhea $(1,3)$. Cryptosporidiosis, coccidiosis and giardiasis that cause diarrhea are critical protozoan diseases for newborns. These protozoer diseases cause diarrhea by themselves and/or as mixed infections (4-6). These factors lead to diarrhea by causing abnormal motility, hypersecretion, changes in ion transport and permeability disorders in the intestinal mucosa (1). Metabolic changes owing to neonatal diarrhea and symptomatic treatment of diarrhea are similar, but even so there are differences in etiologic treatment. Despite chemotherapeutic advances, neonatal diarrhea is still progressing with high morbidity and mortality. Furthermore, growth retardation and high treatment costs due to diarrhea cause great losses in the national economy $(3,7)$.

\section{Cryptosporidiosis Treatment}

Cryptosporidium parvum (C. parvum) is an intracellular protozoan parasite that causes gastrointestinal disease and diarrhea. Cryptosporidiosis is a vital neonatal infection in calves, lambs and kids with high morbidity (8). The epidemics of diarrhea caused by cryptosporidiosis are encountered in many countries. Deaths caused by cryptosporidiosis, which is an important reason of neonatal diarrhea in our country, cause serious economic losses (9).
The main problem of cryptosporidiosis is the lack of a efficient method or drug for disease prevention and treatment (10). Because oocysts are resistant to environmental conditions and most of the disinfectants (11). More than 200 active substances have been tested against cryptosporidiosis to date (12). Although some of these substances tested have shown promising effects for the treatment of the disease, none of these drugs have completely eliminated the disease or fully got the clinical findings under control. Clinical and parasitological responses to the treatment of the disease vary depending on the immune system of animals, duration of antiprotozoer treatment and the use of other drugs in treatment (10). The drugs used in treatment are shown in Table 1.

Paromomycin, an aminoglycoside derivative, is one of the appropriate antibiotics so as to take $C$. parvum infections under control. Paromomycin shows antiprotozoer effect against the substance by being absorbed in small amounts along therestrictive apical membrane that binds extra cytoplasmic parasites. (10). When paromomycin is used prophylactically at $100 \mathrm{mg} /$ $\mathrm{kg}$ in calves and kids for 11 days, it not only reduces the oocyst excretion in the faeces but also shortens the oocyst excretion period $(13,14)$. However, oocyst excretions can be observed in animals once again right after the use of the drugs is prophylactically over (15). When paromomycin is therapeutically used in lambs at different doses and on different days 
Table 1 Drugs used in cryptosporidiosis, doses, application times and routes of administration

\begin{tabular}{|c|c|c|c|}
\hline Drugs & & Dosage/Application time & Administration route \\
\hline \multirow{2}{*}{ Paromomycin } & Treatment & $100 \mathrm{mg} / \mathrm{kg}$, once a day, 3-5 days & \multirow{2}{*}{ By adding into drinking water or milk } \\
\hline & Prophylactic & $100 \mathrm{mg} / \mathrm{kg}$, once a day, 11 days & \\
\hline \multirow{2}{*}{ Halofuginone } & Treatment & $0.1 \mathrm{mg} / \mathrm{kg}$, once a day, 7 days & \multirow{2}{*}{ Oral } \\
\hline & Prophylactic & $0.1 \mathrm{mg} / \mathrm{kg}$, once a day, during 7 days after birth & \\
\hline Azithromycin & Treatment & $1500 \mathrm{mg} /$ day, 7 days & Oral \\
\hline Decoquinate & Treatment & $2.5 \mathrm{mg} / \mathrm{kg}$, once a day, 21 days & Oral \\
\hline \multirow[b]{2}{*}{$\begin{array}{l}\text { Organic acids } \\
\text { Activated charcoal }\end{array}$} & Treatment & $\begin{array}{l}\text { Calves; } 60 \mathrm{ml} \text {, twice a day, } 4 \text { days. } \\
\text { Lambs and kids; } 10 \mathrm{ml}, 4 \text { days, twice a day. }\end{array}$ & \multirow[b]{2}{*}{$\begin{array}{l}\text { By adding into the milk or by directly drinking } \\
\text { the solution. }\end{array}$} \\
\hline & Prophylactic & $\begin{array}{l}\text { Calves; } 60 \mathrm{ml} / \text { day, } 7 \text { days, once a day, during } 7 \text { days } \\
\text { after birth. } \\
\text { Lambs and kids; } 10 \mathrm{ml} / \text { day, } 7 \text { days, once a day, during } \\
7 \text { days after birth. }\end{array}$ & \\
\hline
\end{tabular}

(100 mg/kg, 3 per day, $200 \mathrm{mg} / \mathrm{kg}, 2$ per days), it diminishes the oocyst excretion and severity of clinical findings (16). When all these data are taken into consideration, paromomycin can be applied in both prophylaxis and treatment of cryptosporidiosis.

Halofuginone lactate, a derivative of quinazolinone, is an effective antiprotozoal agent against lactate eimeria, theileria and cryptosporidia (17). Halofuginone shows a cryptosporidiostatic effect on sporozoite and merozoite stages of C. parvum (18). Halofuginone lactate is frequently used in the prophylaxis and treatment of cryptosporidiozis in calves, lambs and kids (18-21). In the study conducted over calves, animals in the treatment group were treated with halofuginone lactate at a dose of $0.1-0.12 \mathrm{mg} / \mathrm{kg}$ for 7 days $(18,20,21)$. In these studies, the use of halofuginone lactate in reducing oocyst excretion is an appropriate treatment option whereas the efficacy of the active substance in the treatment of diarrhea is controversial. In the studies, because reoccurrence of oocyst excretion of some animals after treatment indicates that halofuginone cannot completely prevent the life cycle of parasite. In addition to this, halofuginone lactate treatment alleviates the clinical findings regarding to cryptosporidiosis and decreases mortality rates in calves $(10,22)$. Prophylactically use of halofuginone lactate $(0.1 \mathrm{mg} / \mathrm{kg})$ in calves during the first 7 days following birth significantly reduces the oocyst excretion rate in animals (22). The use of the active substance in small ruminants at the indicated dose and time decreases the oocyst excretion in the faeces (10). In general, halofuginone lactate can be effectively used in both prophylaxis and treatment of cryptosporidiosis (at a dose of $0.1 \mathrm{mg} / \mathrm{kg}$ for 7 days) (19-22).

Decoquinate is an antiprotozoer substance that can be used in the treatment of cryptosporidiosis and toxoplasmosis, especially in coccidiosis (23). It has been reported that the use of decoquinate in experimentally infected calves $(2.5 \mathrm{mg} / \mathrm{kg}$, for 21 days from birth) may be effective in treatment (10). However, in another study where decoquinat was used at a dose of 2 $\mathrm{mg} / \mathrm{kg}$ twice a day for 28 days from birth, it was stated that the active substance had no effect on oocyst excretion or clinical findings (24). In a comparative study conducted about efficacy of halofuginone $(0.1 \mathrm{mg} / \mathrm{kg})$ and decoquinate $(2-5 \mathrm{mg} / \mathrm{kg})$, it was found that halofuginone significantly reduced the excretion of oocysts compared to decoquinate (25).
Nitazoxanide is a nitratiazole benzamide derivative antiparasitic agent effective against most helminths, bacteria and protozoa. The antiprotozoer effect of nitazoxanide is different from its antibacterial effect. The antiprotozoer effect on C. parvum is thought to be similar to its effect on Neospora caninum (N. Caninum). After taking nitazoxanide by an oral way, it turns into an active metabolite tizoxanide by being hydrolyzed (10). In vitro, it was determined that nitazoxanide inhibited $N$. caninum protein disulfide isomerase enzyme and restrained the metabolic activity of the parasite in N. caninum (26). Nitazoxanide is applied for the treatment of cryptosporidiosis in AIDS patients along with anti-retroviral therapy in humans. There is little information about its effect against cryptosporidiosis in animals (10). In a study where nitazoxanide was used for treatment and prophylaxis in calves (twice a day by adding $15 \mathrm{mg} / \mathrm{kg}$ milk to body weight), it was reported that the active substance had no effect on oocyst excretion (27). In another study, however, it was reported that when nitazoxanide was used in calves $(1.5 \mathrm{~g}$, twice a day, 5 days), the oocyst excretion period was shortened and fecal consistency arranged (28).

Azithromycin is a macrolide antibiotic used for immunocompromised humans and the treatment of cryptosporidiosis in animals. Thanks to azithromycin treatment, oocyst excretion was suppressed in naturally infected calves $(1500 \mathrm{mg} /$ day, 7 days) and it was reported to contribute to clinical recovery (29). However, azithromycin is an expensive active substance and there are not enough studies to evaluate the efficacy of the drugs for the disease (10).

Activated charcoal used along with organic acids obtained by distillation and putrification from tree barks can be used for the protection and treatment of cryptosporidiosis (30). While activated charcoal affects normal flora very few in the intestinal system, it contributes to the reduction of the number of oocyst by adsorbing oocyst of Cryptosporidium spp. On the contrary, organic acids reduce the number of oocyst by aiming at replacing disinfectants against $C$. parvum oocyst. It is also thought that organic acids have an inhibitory effect on the development of active substances. It has been reported that oocyst excretion in animals has reduced by oral administration of activated charcoal containing organic acids to calves $(10 \mathrm{~g}$ solution with milk substitute feed, at intervals of 8 hours for 4 days) experimentally infected with C. parvum (31). In another study, it was reported that oocyst excretion reduced and cli- 
Table 2 Drugs used in coccidiosis, doses, application time and routes of administration

\begin{tabular}{|c|c|c|c|}
\hline Drugs & & Dosage/Application time & Administration route \\
\hline Sulfamethazine & Treatment & $140 \mathrm{mg} / \mathrm{kg}$, once a day, 3 days. & Oral \\
\hline Sulfaquinoxaline & Treatment & $60 \mathrm{mg} / \mathrm{kg}$, once a day, 4 days. & Oral \\
\hline Sulfadimethoxin & Treatment & $\begin{array}{l}\text { First day } 55 \mathrm{mg} / \mathrm{kg} \text { as a half dose in the following days, } \\
\text { once a day, } 4 \text { days. }\end{array}$ & Oral \\
\hline Sulfathiazol & Treatment & 150 mg/kg, 3-6 days. & Oral \\
\hline \multirow[t]{2}{*}{ Amprolium } & Treatment & $\begin{array}{l}\text { Calves; } 10 \mathrm{mg} / \mathrm{kg} \text {, once a day, } 5 \text { days. } \\
\text { Lambs; } 50 \mathrm{mg} / \mathrm{kg} \text {, once a day, } 5 \text { days. } \\
\text { Kids; } 100 \mathrm{mg} / \mathrm{kg} \text {, once a day, } 4 \text { days. }\end{array}$ & \multirow[t]{2}{*}{ By adding to drinking water } \\
\hline & Prophylactic & $\begin{array}{l}\text { Calves; } 5 \mathrm{mg} / \mathrm{kg} \text {, once a day, } 3 \text { weeks. Lambs; } 50 \mathrm{mg} / \mathrm{kg} \text {, } \\
\text { once a day, } 3 \text { weeks. }\end{array}$ & \\
\hline Decoquinate & Prophylactic & $0.5-1 \mathrm{mg} / \mathrm{kg}$, at least 28 days. & By adding to feed \\
\hline \multirow[t]{2}{*}{ Toltrazuril } & Treatment & $\begin{array}{l}\text { Calves; } 5 \mathrm{mg} / \mathrm{kg} \text {, single dose. } \\
\text { Lambs and kids; } 20 \mathrm{mg} / \mathrm{kg} \text {, single dose. }\end{array}$ & \multirow[t]{2}{*}{ Oral } \\
\hline & Prophylactic & Same as treatment doses. & \\
\hline Diclazuril & Prophylactic & $1 \mathrm{mg} / \mathrm{kg}$, single dose. & Oral \\
\hline
\end{tabular}

nical findings improved when mixtures (2-3 times a day, 3.75 $\mathrm{g} /$ day dose, as a suspension in the milk substitute feed) was provided to the kids aged 3-17 days (30).

It has been reported that oral bovine serum concentrate used for passive immunotherapy reduces oocyst excretion in calves and reduces the severity of clinical symptoms. (5 days at $57 \mathrm{~g} /$ day in added milk replacer, 2 days at $57 \mathrm{~g} /$ day by blending with rehydration liquid). Three potential different mechanisms have been proposed for the efficacy of bovine serum concentrate in reducing the severity of cryptosporidiosis. The first possible mechanism of effects is that immunoglobulins in oral bovine serum concentrate may cause a decrease in the number of parasites over the intestinal system. The second possible mechanism is that growth factors in bovine serum increase the repair of intestinal cells. The third possible mechanism is that bovine serum concentrate may reduce the invasion and replication of the parasite in reducing the severity of infection (32).

\section{Coccidiosis Treatment}

Coccidiosis is a protozoal infection caused by coccidia parasites of the Eimeria genus, leading to diarrhea by affecting particularly young ruminants (33). As a result of intracellular growth and proliferation of the active substances, the damage in the intestinal cells and mucosa occurs. Mortality, growth retardation and veterinary expenses are among the economic damages of the disease to livestock $(33,34)$.

In a herd, managing economy can be successfully accomplished in coccidiosis after obtaining detailed information and management principles about the disease. Unless such information is observed, systematic treatments are not appropriate. Preventive measures are the key to controlling coccidiosis. Effective methods for disease prevention involves minimizing theme of susceptible young animals with infective oocyst and administration of coccidiostatic drugs prophylactically injected to animals during agamous developmental stages of the parasites. After the oocysts are transferred to the intracellular form, the effects of drugs on the parasites are limited (33-35).

Anticoccidial drugs have different modes of action on the endogenous phase of the life cycle of eimeria species (33). Sulfanomides, amprolium and decoquinate parasites make an effective impression in the early stages of life cycle $(33,36)$. Toltrazuril and diclazuril are molecules that are effective in all stages of life cycles of coccidia. These active substances can be used both in the treatment of the disease and prophylaxis of the disease (33). The active substances used in coccidiosis are shown in Table 2.

Sulfanomides are fundamentally effective on the agamous growth phase of the parasites. Sulfanomides are frequently carried out in treatment, but still they do not have sufficient effect on gamonts. However, sulfanomides are effective in controlling secondary bacterial infections in cases of coccidiosis (36). Sulfaquinoxaline, sulfamethazine, sulfadimethoxine and sulfathiazole are sulfanomide derivatives implemented in the treatment of coccidiosis. There is a risk of toxication due to long term use or overdose of sulfanomides (37).

The structures that amprolium targets are meronts. This active substance has low toxicity and is conducted by adding to drinking water of animals throughout 3-5 days (36). Amprolium is recommended to be used for 10 days in cattle, at $50-62.5 \mathrm{mg} /$ $\mathrm{kg}$ for sheep through 5 days, and at $100 \mathrm{mg} / \mathrm{kg}$ in 4 days for goats. Given that amprolium is an antagonist of vitamin B1, it should not be used for a long time and vitamin B1 supplements must be implemented. In spite of hygienic measures, amprolium can be orally used for 3 weeks by adding $5-10 \mathrm{mg}$ / $\mathrm{kg}$ milk or drinking water as long as outbreaks of coccidiosis cannot be prevented in the herd $(37,38)$.

Decoquinate is used as anticoccidial drugs that are injected into the feed in many countries. Long-term use is recommended as decoquinate coccidia is effective in only initial phases of the life cycle (36). It was determined that oocyst excretion decreased when $0.5-1 \mathrm{mg} / \mathrm{kg}$ decoquinate was injected to the rations of experimentally infected calves. Furthermore, It is reported that decoquinate positively contributes to the growth rate of calves. As a result, when decoquinate is implemented by adding $0.5-1 \mathrm{mg} / \mathrm{kg}$ dose to the animal feed, it successfully suppresses the formation of oocyst and prevents cases of coccidiosis (39). 
Table 3 Drugs used in giardiasis, doses, application time and routes of administration

\begin{tabular}{|c|c|c|c|}
\hline Drugs & & Dosage/Application time & Administration route \\
\hline \multirow[b]{2}{*}{ Albendazole } & Treatment & $20 \mathrm{mg} / \mathrm{kg}$, once a day, 3 days. & \multirow[b]{2}{*}{ Oral } \\
\hline & Prophylactic & $\begin{array}{l}\text { Calves, } 5 \mathrm{mg} / \mathrm{kg} \text {, once a day, at } 27 \text { days interval, } 3 \\
\text { times. }\end{array}$ & \\
\hline Fenbendazole & Treatment & $10 \mathrm{mg} / \mathrm{kg}$, once a day, 3 days. & Oral \\
\hline Paromomycin & Treatment & $50-75 \mathrm{mg} / \mathrm{kg}$, once a day, 5 days. & Oral \\
\hline Dimetridazole & Treatment & Calves; $50 \mathrm{mg} / \mathrm{kg}$, once a day, 5 days. & Oral \\
\hline Secnidazole & Treatment & $\begin{array}{l}\text { Calves; } 30-400 \mathrm{mg} / \mathrm{kg} \text {, single dose. } \\
\text { Lambs; } 10 \mathrm{mg} / \mathrm{kg} \text {, single dose. }\end{array}$ & Oral \\
\hline
\end{tabular}

Benzene acetonitrile compounds (toltrazuril, diclazuril) are effective against all stages of development in the life cycle of eimeria. These compounds are suitable for both treatment and prophylactic use (33). The single use of toltrazuril at a dose of $15 \mathrm{mg} / \mathrm{kg}$ decreases oocyst excretion and provides clinical findings improvement in infections caused by Eimeria bovis (E. bovis) and Eimeria zuernii (E. zuernii) for calves (40). It was reported that coccidiosis could be under control by using a single dose 1 week before the emregence of expected outbreaks. Toltrazuril dose rate that will be implemented to kids is recommended to be double dose rate approximately rather than the dose which is going to be conducted to cattle and sheep (33). It was stated that the cases of coccidiosis attached to E. bovis and E. zuernii was prevented thanks to administration of diclazuril prophylactically at a dose of $1 \mathrm{mg} / \mathrm{kg}$ with single dose (36).

The regular use of anticoccidial drugs in the poultry sector has provided eimeria species develop resistance to these drugs. However, it is not certain whether eimeria species will develop resistance to anticoccidial treatment in cattle or not, it should be remembered that a potential risk may ocur (36).

\section{Giardiasis Treatment}

Giardiasis is an important infection arose from Giardia intestinalis ( $G$. intestinalis), which is an intestinal protozoan with flagella, causing diarrhea, weight loss and lethargy in farm animals (8, $11,39)$. It is one of the most common parasites causing loss of yield in ruminants. Most mammals are susceptible to infections caused by $G$. intestinalis (11).

Many active substances are known to be effective against giardia. However, no drug has been licensed to use in the giardiasis treatment for ruminants nowadays (41). The active substances used in giardiasis are shown in Table 3.

Nitroimidozols such as metronidazole, tinidazole, quinacrine or furazolidine are extensively used in the treatment of giardiasis for humans. In veterinary medical science, metronidazole and secnidazole are used in pet animals, calves and lambs (39, 42). It has been reported that the administration of a single dose of secnidazole, a nitroimidazole derivative in lambs and calves, significantly reduces cyst excretion $(42,43)$. Volpato et al. reported that secnidazole, which was administered as a single dose $(400 \mathrm{mg} / \mathrm{kg})$ in calves, treated giardiasis and that drug continued the efficiency for 30 days (43). Besides, Toros and Ural reported that secnidazole administered at a single dose of $30 \mathrm{mg} / \mathrm{kg}$ in calves resets cyst excretion (44).

Benzimidazoles, extensive-spectrum antihelmentics, are other compounds used in the treatment of giardiasis. Benzimi- dazoles have a high safety margin and selective toxicity (41). In vitro studies, it has been reported that benzimidazoles are more effective on giardiasis than metronidazole and tinidazole $(41,45,46)$. Benzimidazoles affect tubulin polymerization, an important component of cell skeletal structures of giardia trophozoites. In this way, all functional activities of the tubuline structures such as median line and ventral disc are limited. In conclusion, benzimidazoles prevent trophozoites from attaching to intestinal mucosa and colonization (14). Fenbendazole and albendazole reduce cyst excretion in calves $(41,47,48)$. Fenbendazol, provides regeneration in the clinical appearance of the disease by reducing the duration and peak level of cyst excretion $(41,49)$. The doses of benzimidazoles required for giardiasis treatment are higher than those used in antihelminthic treatment (41). When albendazole is used $20 \mathrm{mg} / \mathrm{kg}$ for 3 days and fenbendazole is used at $10 \mathrm{mg} / \mathrm{kg}$ for 3 days, it is quite effective to eliminate the infection $(39,42,50)$. Since the duration of treatment is more important than the doses in the prophylaxis of the disease, it is recommended that benzimidazoles be administered in small doses and at frequent intervals in the studies $(47,49)$.

Paromomycin Cryptosporidium spp., regarded as effective against protozoan parasites such as a broad-spectrum, is an aminoglycoside derivative antibiotic (10). Paromomycin, by being attached to the small subunit of rRNA, inhibits protein synthesis which has a direct effect on giardia (41). The active substances showing poor absorption from the gastro-intestinal system is well tolerated by calves (15). In experimentally infected calves $(50-75 \mathrm{mg} / \mathrm{kg} /$ day for 5 days) it was determined that paromomycin reduces cyst excretion effectively (41). In a study examining the efficacy of albendazole and paromomycin on the disease in lambs with giardiasis, it was stated that paromomycin implemented at a dose of $100 \mathrm{mg} / \mathrm{kg} /$ day for 3 days was more effective than albendazole (50).

Drugs used in the treatment of giardiasis are effective against giardia, but cyst excretions can be observed in animals within 2-3 weeks after treatment. Since giardia cysts can survive up to 1 week in faeces and up to 7 weeks in soil, the action time of most active substances may be insufficient to protect animals from re-infections (14). The studies emphasize the importance of establishing a combined control program that includes cleaning, disinfection and treatment protocols of animals in order to minimize re-infections after treatment $(11,41)$.

\section{CONCLUSION}

The complete treatment depending on the cause in diarrhea which causes great harm to the economy of our country is the most important factor affecting the success of treatment. It is required to be performed at appropriate dose and time throu- 
gh appropriate drug selection in order to eliminate not only the infection but the risks of re-infection as well. This study, which we think that it will be the current reference guide for veterinary practioner, will also provide positive contributions to the protection of herd health.

\section{REFERENCES}

1. Özkan C, Akgül Y. Neonatal İshalli Buzağılarda Hematolojik,Biyokimyasal ve Elektrokardiyografik Bulgular. Yüzüncü Y1l Üniversitesi Vet Fakültesi Derg. 2004;15(1):1239.

2. Savaş T. Oğlak Büyütme: Sorunlu Noktalar Üzerinde Bir Değerlendirme. 2007;48(1):44-53.

3. Aydoğdu U. Kuzularda Neonatal Mortalite. Cumhuriyet Üniv Sağ Bil Enst Derg. 2016;2(1):37-46.

4. Altuğ N, Yüksek N, Özkan C, Keleș İ, Bașbuğan Y. Neonatal Buzağ İshallerinin Immunokromotografik Test Kitleri İle Hızlı Etiyolojik Teşhisi. YYU Vet Fak Derg. 2013;24(3):123-8.

5. Göz Y, Altuğ N, Yüksek N, Özkan C. Parasites detected in neonatal and young calves with diarrhoea. Bull Vet Inst Pulawy. 2006;50(3):345-8.

6. Ozdal N, Tanritanir P, Goz Y, Deger S, Kozat S. Parasitic protozoans (Eimeria, Giardia, and Cryptosporidium) in lambs with diarrhoea in the van province (Turkey). Bull Vet Inst Pulawy. 2009;53(1):47-51.

7. Al M, Balıkçı E. Neonatal ishalli buzağılarda rotavirus, coronavirus, E. coli K99 ve Cryptosporidium parvum'un hizli test kitleri ile teşhisi ve enteropatojen ile maternal immünite ilişkisi. FÜ Sağ Bil Vet Derg. 2012;26(2):73-8.

8. Sahinduran, S. Protozoan diseases in farm ruminants. In A Bird'sEye View of Veterinary Medicine. 2012. In Tech. Available from: http://www.intechopen.com/books/a-bird-s-eye-view-of-veterinary-medicine/protozoan-diseases-in-farmruminants

9. Sevinç F. Ruminantlarda Cryptosporidiosis. Vet Bil Deg. 2004:4:79-84

10. Shahiduzzaman M, Daugschies A. Therapy and prevention of cryptosporidiosis in animals. Vet Parasitol. 2012;188(34):203-14.

11. O'Handley RM, Olson ME. Giardiasis and Cryptosporidiosis in Ruminants. Vet Clin North Am - Food Anim Pract. 2006;22(3):623-643.

12. Gargala G. Drug treatment and novel drug target against Cryptosporidium. Parasite. 2008;15(3):275-281.

13. Chartier C, Mallereau M-P, Naciri M. Prophylaxis using paromomycin of natural cryptosporidial infection in neonatal kids. Prev Vet Med. 1996;25(3-4):357-361.

14. Fayer R, Ellis W. Paromomycin is effective as prophylaxis for cryptosporidiosis in dairy calves. J Parasitol. 1993;79(5):771774.

15. Grinberg A, Lopez-Villalobos N, Markovics A, Kosak A, Galindez J, Tranquillo VM. Controlling the onset of natural cryptosporidiosis in calves with paromomycin sulphate. Vet Rec. 2002;151(20):606-608.

16. Viu M, Quilez J, Sánchez-Acedo C, Del Cacho E, López-Bernad F. Field trial on the therapeutic efficacy of paromomycin on natural Cryptosporidium parvum infections in lambs. Vet Parasitol. 2000;90(3):163-170.

17. Najdrowski M, Heckeroth AR, Wackwitz C, Gawlowska S, Mackenstedt U, Kliemt D, et al. Development and validation of a cell culture based assay for in vitro assessment of anticr- yptosporidial compounds. Parasitol Res. 2007;101(1):161-167.

18. Jarvie BD, Trotz-Williams LA, McKnight DR, Leslie KE, Wallace MM, Todd CG, et al. Effect of halofuginone lactate on the occurrence of Cryptosporidium parvum and growth of neonatal dairy calves. J Dairy Sci. 2005;88(5):1801-1806.

19. Giadinis ND, Papadopoulos E, Panousis N, Papazahariadou M, Lafi SQ, Karatzias H. Effect of halofuginone lactate on treatment and prevention of lamb cryptosporidiosis: An extensive field trial.J Vet Pharmacol Ther. 2007;30(6):578-582.

20. Lefay D, Naciri M, Poirier P, Chermette R. Efficacy of halofuginone lactate in the prevention of cryptosporidiosis in suckling calves. Vet Rec. 2001;148(4):108-112.

21. Naciri M, Mancassola R, Yvoré P, Peeters JE. The effect of halofuginone lactate on experimental Cryptosporidium parvum infections in calves. Vet Parasitol. 1993;45(3-4):199-207.

22. Trotz-Williams LA, Jarvie BD, Peregrine AS, Duffield TF, Leslie KE. Efficacy of halofuginone lactate in the prevention of cryptosporidiosis in dairy calves. Vet Rec. 2011;168(19):509.

23. Lindsay DS, Woods KM, Upton SJ, Blagburn BL. Activity of decoquinate against Cryptosporidium parvum in cell cultures and neonatal mice. Vet Parasitol. 2000;89(4):307-311.

24. Moore DA, Atwill ER, Kirk JH, Brahmbhatt D, Alonso LH, Hou L, et al. Prophylactic use of decoquinate for infections with Cryptosporidium parvum in experimentally challenged neonatal calves. J Am Vet Med Assoc. 2003;223(6):839-845.

25. Lallemond M, Villeneuve A, Belda J, Dubreuil P. Field study of the efficacy of halofuginone and decoquinate in the treatment of crytosporidiosis in veal calves. Vet Rec. 2006;159(20):672-677.

26. Naguleswaran A, Alaeddine F, Guionaud C, Vonlaufen N, Sonda S, Jenoe P, et al. Neospora caninum protein disulfide isomerase is involved in tachyzoite-host cell interaction. Int J Parasitol. 2005;35(13):1459-1472.

27. Schnyder M, Kohler L, Hemphill A, Deplazes P. Prophylactic and therapeutic efficacy of nitazoxanide against Cryptosporidium parvum in experimentally challenged neonatal calves. Vet Parasitol. 2009;160(1-2):149-154.

28. Ollivett TL, Nydam D V., Bowman DD, Zambriski JA, Bellosa ML, Linden TC, et al. Effect of nitazoxanide on cryptosporidiosis in experimentally infected neonatal dairy calves. J Dairy Sci. 2009;92(4):1643-1648.

29. Elitok B, Elitok ÖM, Pulat H. Efficacy of azithromycin dihydrate in treatment of cryptosporidiosis in naturally infected dairy calves. J Vet Intern Med. 2005;19(4):590-593.

30. Paraud C, Pors I, Journal JP, Besnier P, Reisdorffer L, Chartier C. Control of cryptosporidiosis in neonatal goat kids: Efficacy of a product containing activated charcoal and wood vinegar liquid (Obionekk ${ }^{\circledR}$ ) in field conditions. Vet Parasitol. 2011;180(3-4):354-357.

31. Watarai S, Tana, Koiwa M. Feeding activated charcoal from bark containing wood vinegar liquid (Nekka-Rich) is effective as treatment for cryptosporidiosis in calves. J Dairy Sci. 2008;91(4):1458-1463.

32. Hunt E, Fu Q, Armstrong MU, Rennix DK, Webster DW, Galanko JA, et al. Oral bovine serum concentrate improves cryptosporidial enteritis in calves. Pediatr Res. 2002;51(3):370_ 376.

33. Chartier C, Paraud C. Coccidiosis due to Eimeria in sheep and goats, a review. Small Rumin Res. 2012;103(1):84-92.

34. Jolley WR, Bardsley KD. Ruminant Coccidiosis. Vet Clin North Am - Food Anim Pract. 2006;22(3):613-621. 
35. Mundt HC, Bangoura B, Mengel H, Keidel J, Daugschies A. Control of clinical coccidiosis of calves due to Eimeria bovis and Eimeria zuernii with toltrazuril under field conditions. Parasitol Res. 2005;97:134-142

36. Daugschies A, Najdrowski M. Eimeriosis in cattle: Current understanding. J Vet Med Ser B Infect Dis Vet Public Heal. 2005;52(10):417-427.

37. Aksoy G, Kurtdede A, Gül Y, Ağaoğlu TZ, Dodurka T, Akgül Y, Kaymaz Akdoğan A, Kalınbacak A, Or E, Keleș I, Bakirel U, Erdoğan MH, Citil M, İssi M. Geviș Getiren Hayvanların Iç Hastalıkları. In: Gül Y, editör. 3. Baskı. Malatya: Medipres Matbaacilik; 2012. s:144-148.

38. Engidaw S, Anteneh M, Demis C. Coccidiosis in Small Ruminants. African J Basic Appl Sci. 2015;7(6):311-319.

39. Radostits OM, Gay CC, Hinchcliff KW, Constable PD. Veterinary Medicine A textbook of the diseases of cattle, horses, sheep, pigs and goats. 10th edition, W.B. Saunders Co; 2008. p: $1483-1540$

40. Mundt HC, Daugschies A, Uebe F, Rinke M. Efficacy of toltrazuril against artificial infections with Eimeria bovis in calves. Parasitol Res. 2003;90(3):166-167.

41. Geurden T, Vercruysse J, Claerebout E. Is Giardia a significant pathogen in production animals? Exp Parasitol. 2010;124(1):98-106.

42. Ural K, Aysul N, Voyvoda H, Ulutas B, Aldemir OS, Eren H. Single dose of secnidazole treatment against naturally occuring Giardia duodenalis infection in Sakiz lambs. Rev MVZ Córdoba. 2014;19(1):4023-4032.

43. Volpato A, Fortuoso BF, Campigotto G, Glombowsky P, Bottari NB, Lopes LS, et al. Secnidazole for control of giardiasis in dairy calves. Exp Parasitol. 2018;189:16-18.

44. Toros G, Ural K. Single dose secnidazole treatment efficiency against naturally occuring Giardia duodenalis infection in calves. Rev MVZ Córdoba. 2018;23(2):6660-6670.

45. Edlind TD, Hang TL, Chakraborty PR. Activity of the anthelmintic benzimidazoles against Giardia lamblia in vitro. J Infect Dis. 1990;162(6):1408-14011.

46. Meloni BP, Thompson RCA, Reynoldson JA, Seville P. Albendazole: a more effective antigiardial agent in vitro than metronidazole or tinidazole. Trans R Soc Trop Med Hyg. 1990;84(3):375-379.

47. O’Handley RM, Olson ME, McAllister TA, Morck DW, Jelinski M, Royan G, et al. Efficacy of fenbendazole for treatment of giardiasis in calves. Am J Vet Res. 1997;58(4):384-388.

48. Xiao L, Saeed K, Herd RP. Efficacy of albendazole and fenbendazole against Giardia infection in cattle. Vet Parasitol. 1996;61(1-2):165-170.

49. O'Handley RM, Cockwill C, Jelinski M, McAllister TA, Olson ME. Effects of repeat fenbendazole treatment in dairy calves with giardiosis on cyst excretion, clinical signs and production. Vet Parasitol. 2000;89(3):209-218.

50. Albay MK, Sahinduran S, Adanir R, Yukari BA, Kose O. Doğal infekte giardiazisli kuzuların tedavisinde albendazol ve iki farklı paromomisin dozunun etkisinin karşılaştırılması. Kafkas Univ Vet Fak Derg. 2011;17(6):1021-1024. 